\title{
Gradient (elevation) vs. disturbance (agriculture) effects on primary Cloud forest in Ecuador: seed predation, seed pathogens, germination
}

Randall W. Myster

\begin{abstract}
Background: Gradients and disturbances affect plant communities. Cloud forests exist on elevational gradients and are often disturbed by being cleared for agriculture, so they present a unique opportunity for the investigation of how gradients and disturbances affect their structure, function and dynamics. The focus of the current study was on seed predation, seed pathogens and seed germination: all key factors in tree recruitment and regeneration.

Methods: Three hundred seeds of three species—Solanum stenophyllum Bitter (Solanaceae: bird-dispersed), Palicourea amethystina (Ruiz \& Pav.) DC. (Rubiaceae: bird-dispersed) and Clusia flaviflora Engl. (Clusiaceae: mammal-dispersed) - were studied at primary $\left(1^{\circ}\right)$ cloud forest at Guandera Reserve. After 2 weeks in the field, losses due to seed predation or pathogens were counted and the remaining seeds were tested for germination. These results were then compared with similar data collected and published previously from a $1^{\circ}$ cloud forest and a secondary $\left(2^{\circ}\right)$ cloud forest, both at Maquipucuna Reserve, Ecuador.

Results: In both closed-canopy forest and tree-fall gaps at Guandera Reserve, S. stenophyllum Dunal seeds suffered the greatest losses to predators, P. amethystina seeds had the greatest germination and C. flaviflora seeds had the greatest losses to pathogens. Comparison with data from Maquipucuna Reserve showed the following: (1) Solanum sp. suffered the greatest losses for seeds lost to seed predators in general but Cecropia sp. and Ficus sp. also had high losses in Maquipucuna $1^{\circ}$ cloud forest; (2) for seeds lost to pathogens, species that lost the most seeds were unique to each study site: Clusia flaviflora seeds at Guandera $1^{\circ}$ cloud forest, Cecropia sp. seeds at Maquipucuna $1^{\circ}$ cloud forest and Piper aduncum L. seeds at Maquipucuna $2^{\circ}$ cloud forest; (3) for seeds that germinated the most, species were again unique to the study site: Palicourea amethystina seeds at Guandera $1^{\circ}$ cloud forest, Otoba gordoniifolia (A. DC.) A.H. Gentry seeds at Maquipucuna $1^{\circ}$ cloud forest and Solanum ovalifolium Dunal seeds at Maquipucuna $2^{\circ}$ cloud forest; and (4) in general, forest types differed significantly for both seed predation and seed pathogens. Within the $1^{\circ}$ cloud forest at Maquipucuna, there was a significant difference among tree seed species for pathogens and a significant difference among the tree seed species for germination, and within the $2^{\circ}$ cloud forest at Maquipucuna, there was a significant difference among tree seed species for pathogens.
\end{abstract}

Conclusions: As elevation increases in $1^{\circ}$ cloud forests, the proportion of seed that germinates remain largely constant, but the major seed loss shifts from being due to predators to being due to pathogens. Conversion to agriculture also leads to seeds mainly lost to predators, but individual species loss levels depended on what crop had been planted previously.

Keywords: Banana, Closed canopy, Guandera Reserve, Maquipucuna Reserve, Pasture, Sugarcane, Tree-fall gap

Correspondence: myster@okstate.edu; http://www.researchgate.

net/profile/Randall_Myster

Biology Department, Oklahoma State University, Oklahoma City, OK 73107,

USA 


\section{Background}

Gradients and disturbances shape plant communities because plants respond to cues created by, or associated with, them (Whittaker 1975; Pickett and White 1985). A fundamental gradient in the Andean mountains is elevation, where cloud forests exist between 1300 and $4000 \mathrm{~m}$ above sea level (a.s.l.: Bush et al. 2004). As elevation increases in these cloud forests, net primary productivity (Girardin et al. 2010), height of emergent trees, canopy height and number of strata all decrease (Myster 2017a). Indeed, plants are more likely to be ecotypes (Myster and Fetcher 2005), and buttresses and climbers are usually replaced by epiphytes (Kappelle 1995; Whitmore 1998) in cloud forests found at higher elevations. Common cloud forest disturbances include landslides (Myster 1997; Myster 2004a, b), conversion to agriculture and pasture (see Myster 2007a) and natural tree-fall (Myster 2015). Thus, the Andes provide an opportunity to examine how gradients (here changes in elevation) and disturbances (here old fields recovering after agricultural use) affect cloud forest structure, function and dynamics. Those effects may be direct-caused by elevation and conversion to agriculture-or indirect, caused by factors associated with elevation (e.g. temperature, humidity) and conversion to agriculture (e.g. soil changes, "signature" of the past crop: Myster and Pickett 1994).

In order to take advantage of this opportunity, the current study expanded on past field experiments on the fate of the seed rain in $1^{\circ}$ and $2^{\circ}$ cloud forest at Maquipucuna Reserve in Ecuador (Myster 2015) by setting up a new seed experiment in closed-canopy forest and in tree-fall gaps at Guandera Reserve in Ecuador. The results of all three studies were then combined to more completely investigate how foresttype $\left(1^{\circ}\right.$ cloud forest at Guandera Reserve, $1^{\circ}$ cloud forest at Maquipucuna Reserve, $2^{\circ}$ cloud forest at Maquipucuna Reserve), microsite (closed-canopy/ tree-fall gap, recovering banana/sugarcane/pasture) and tree seed species affect seed predation, seed pathogens and seed germination, all key components of tree recruitment and regeneration (Myster 2017b) in Andean cloud forests. The aim of this study was to answer the following questions: (1) Does an increase in elevation and the formation of tree-fall gaps affect whether dispersed seeds in cloud forests are taken by predators, infected by pathogens or germinate? (2) Does conversion to agriculture, and the recovery after abandonment, affect whether dispersed seeds in cloud forests are taken by predators, infected by pathogens or germinate? and (3) How do different tree seed species respond to these different conditions?

\section{Methods}

\section{Study sites}

The current study site was the Guandera biological station (GBS:www.jatunsacha.org/guandera-reserve-andbiological-station; Cresswell et al. 1999; Bader et al. 2007; Nierop et al. 2007) situated on the inner flank of the eastern Cordillera at approximately $11 \mathrm{~km}$ from the town of San Gabriel in northern Ecuador $\left(0^{\circ} 36^{\prime} \mathrm{N}, 77^{\circ}\right.$ $\left.42^{\prime} \mathrm{W}\right)$. The area is of volcanic origin and has deep dark humic Andosols developed in old volcanic ashes. Annual precipitation is $1700 \mathrm{~mm}$. Diurnal temperature fluctuations range from 4 to $15{ }^{\circ} \mathrm{C}$ but annual temperature fluctuations are low (monthly means of maximum temperature vary between 12 and $15{ }^{\circ} \mathrm{C}$ : Bader et al. 2007). Within the GBS, $1^{\circ}$ cloud forest occurs between the agricultural areas, mainly potato (Solanum tuberosum L.) cultivation below $3300 \mathrm{~m}$ a.s.l., and the páramo grasslands (Myster 2012a) above $3640 \mathrm{~m}$ a.s.l. The GBS consists of upper montane cloud forest at lower elevations and sub-alpine dwarf forest at higher elevations. The upper montane cloud forest is dominated by the trees Clusia flaviflora Engl. (Clusiaceae), Ilex colombiana Cuatrec. (Aquifoliaceae), Weinmannia cochensis Hieron. (Cunoniaceae), Miconia tinifolia Naudin (Melastomataceae) and Gaiadendron punctatum (Ruiz and Pavón) G.Don. (Loranthaceae) and the epiphytes Tillandsia sp. (Bromeliaceae) and Blechnum schomburgkii (Klotzsch) C.Chr. (Blechnaceae). The sub-alpine dwarf forest is dominated by the trees Miconia tinifolia and Weinmannia cochensis, a shrub Gaiadendron punctatum, a fern Blechnum schomburgkii and a bamboo Neurolepis aristata (Munro) Hitchc. (Poaceae: Cresswell et al. 1999).

\section{Experimental design and execution}

Ten $1^{\circ}$ cloud forest areas were selected randomly at GBS in May 2015. Five had new tree-fall gaps between 100 and $300 \mathrm{~m}^{2}$ in area (Brokaw 1982) and five were in closed-canopy forest. Ripe fruits were collected by hand (using gloves to reduce transfer of infections or human odor) from one local individual of Solanum stenophyllum Bitter (Solanaceae: bird-dispersed), one local individual of Clusia flaviflora Engl. (Clusiaceae: mammaldispersed) and one local individual of Palicourea amethystina (Ruiz \& Pav.) DC. (Rubiaceae: birddispersed). Seed species are ordered by increasing seed mass (found on www.data.kew.org/sid/). Seeds were examined for damage using a dissecting microscope and by floating them in water. Visually damaged seeds and those that floated were discarded. Ten viable seeds of each of the three test species were then placed in three separate plastic 9-cm-diameter Petri dishes spaced $50 \mathrm{~cm}$ apart and placed in the centre of each closedcanopy forest area and in the centre of each tree-fall gap. Three dishes per gap $\times$ ten gaps gave a total of 30 
dishes and 300 seeds per species. Plastic seed mimics were also placed in each dish to examine whether seeds were removed by biotic agents (e.g. insects, birds, mammals) or by abiotic conditions (e.g. wind, rain). These mimics were constructed from plastic purchased in Quito to match seed size, shape and colour.

After 2 weeks in the field, seed loss from each dish was counted. Animals were assumed to be the agents of removal because chewed seeds and husks and smallmammal faeces were found in or near the dishes and because plastic seed mimics in the dishes were not taken. It was also assumed that the seeds taken did not germinate later (Notman and Gorchov 2001), and there is, to date, no reason to question this (Myster 2007a; Myster 2014b). The remaining seeds were placed on moist paper, in sealed plastic Petri dishes, in a shade house at GBS for incubation. After 4 weeks, seeds that germinated, seeds that did not germinate and had extensive fungal infection (i.e. lost to pathogenic attack: Myster 2004b) and "other" seeds were counted after being viewed under a dissecting microscope.

\section{Data analysis}

Data collected previously (Myster 2015) were included in the analysis. That study site was the Maquipucuna Reserve (MR:www.maqui.org: Sarmiento 1997; Myster and Sarmiento 1998, Rhoades and Coleman, 1999, Rhoades et al., 1998, Myster 2015) between 1200 and $1800 \mathrm{~m}$ a.s.l. in elevation and $20 \mathrm{~km}$ from Nanegalito, Ecuador $\left(0^{\circ} 05^{\prime} \mathrm{N}, 78^{\prime} 37^{\prime \prime} \mathrm{W}\right)$. The MR has a mean temperature of $18{ }^{\circ} \mathrm{C}$ and an annual precipitation of $3198 \mathrm{~mm}$ (measured from Nanegal: Sarmiento 1997). The MR consists of $1^{\circ}$ cloud forest (Myster 2014b) and $2^{\circ}$ cloud forest of old fields recovering from cultivation of sugarcane (Saccharum officinarum L.) and banana (Musa sp.) and pastures seeded with the grass Setaria sphacelata (Schumach.) Stapf \& C.E.Hubb. Ex Moss (native to Africa: Sarmiento 1997; Zahawi and Augspurger, 1999). Common tree species in the $1^{\circ}$ cloud forest include Erythrina megistophylla Diels (Fabaceae), Nectandra acutifolia (Ruiz \& Pav.) Mez (Lauraceae) and Aegiphila sp. (Verbenaceae: Myster 2014b). There are permanent plots in those old fields, which comprise the longest and largest old-field study in the Neotropics (Myster 2004a; Myster 2004b; Myster 2007a; Myster 2007b; Myster 2014b), funded by the US National Science Foundation (see Myster 2012b for detail). The same protocol was used at MR in both $1^{\circ}$ and $2^{\circ}$, cloud forest and some of those data (Myster 2015) were used here.

Because different tree seed species were used in all three forest types, the species and microsite data were pooled before a one-way ANOVA (SAS 1985) was performed to examine how seed predation, seed pathogens and germination were affected by forest type $\left(1^{\circ}\right.$ cloud forest at Guandera vs. $1^{\circ}$ cloud forest at Maquipucuna vs. $2^{\circ}$ cloud forest at Maquipucuna). The species were then pooled, and a two-way ANOVA was performed to examine how seed predation, seed pathogens and germination were affected by the main effect of forest type $\left(1^{\circ}\right.$ cloud forest at Guandera vs. $1^{\circ}$ cloud forest at Maquipucuna), by the main effect of the microsite (closed-canopy vs. tree-fall gap) and by the interaction of forest-type $\times$ microsite. Finally, each forest type was analysed using three separate two-way ANOVAs to determine how seed predation, seed pathogens and seed germination were affected by:

1. The main effect of microsite (closed-canopy vs. treefall gap for both $1^{\circ}$ cloud forests, recovering sugarcane field vs. recovering banana field vs. recovering seeded pasture for the $2^{\circ}$ cloud forest)

2. The main effect of species and

3. The interaction of microsite $\times$ species

A generalised linear model was not needed for any of the ANOVAs because microsites were not paired. When results from ANOVA were significant, means testing was conducted using the Tukey procedure (SAS 1985) to find those treatment levels that were most significant. Prior to statistical analysis, all data were examined and found to be normally distributed.

\section{Results}

Results of the current study are presented here along with those of the previous study mentioned earlier (all in Tables 1, 2 and 3). For seeds lost to seed predators, (1) the smallest seeds of Solanum stenophyllum had the greatest losses both in closed-canopy forest and in treefall gaps in $1^{\circ}$ cloud forest at Guandera, (2) Cecropia sp. had the greatest losses in closed-canopy forest and

Table 1 The percentage (mean \pm standard error) of the total seeds remaining put out: in closed-canopy forest/in tree-fall gaps in $1^{\circ}$ cloud forest, Guandera biological station

\begin{tabular}{|c|c|c|c|c|}
\hline Species & $\%$ lost to predators & $\%$ lost to pathogens & $\%$ germinated & $\%$ other \\
\hline Solanum stenophyllum & $15 \pm 2 / 17 \pm 1$ & $60 \pm 1 / 63 \pm 1$ & $20 \pm 3 / 10 \pm 2$ & $5 \pm 2 / 10 \pm 2$ \\
\hline Palicourea amethystina & $11 \pm 2 / 13 \pm 2$ & $44 \pm 3 / 47 \pm 1$ & $35 \pm 2 / 27 \pm 2$ & $10 \pm 2 / 13 \pm 1$ \\
\hline Clusia flaviflora & $10 \pm 2 / 9 \pm 1$ & $71 \pm 2 / 75 \pm 1$ & $15 \pm 1 / 12 \pm 1$ & $4 \pm 2 / 4 \pm 2$ \\
\hline Mean \% (rounded) & $12 / 13$ & $58 / 62$ & $23 / 16$ & \\
\hline
\end{tabular}


Table 2 The percentage (mean \pm standard error) of the total seeds remaining put out: in closed-canopy forest/in tree-fall gaps in $1^{\circ}$ cloud forest, Maquipucuna Reserve

\begin{tabular}{lllll}
\hline Species & \% lost to predators & \% lost to pathogens & \% germinated & \% other \\
\hline Cecropia sp. & $88 \pm 1 / 70 \pm 2$ & $8 \pm 2 / 19 \pm 1$ & $4 \pm 1 / 6 \pm 1$ & $0 \pm 1 / 5 \pm 2$ \\
Ardisia websteri & $85 \pm 1 / 81 \pm 1$ & $4 \pm 1 / 10 \pm 1$ & $11 \pm 2 / 9 \pm 1$ & $0 \pm 1 / 0 \pm 1$ \\
Prestoea acuminata & $80 \pm 3 / 88 \pm 2$ & $3 \pm 2 / 5 \pm 2$ & $10 \pm 2 / 6 \pm 2$ & $7 \pm 2 / 0 \pm 1$ \\
Ficus sp. & $82 \pm 2 / 92 \pm 1$ & $5 \pm 1 / 3 \pm 3$ & $8 \pm 1 / 4 \pm 3$ & $5 \pm 1 / 1 \pm 1$ \\
Otoba gordoniifolia & $70 \pm 1 / 68 \pm 1$ & $4 \pm 2 / 10 \pm 3$ & $20 \pm 1 / 10 \pm 2$ & $6 \pm 2 / 12 \pm 1$ \\
Mean \% (rounded) & $81 / 80$ & $5 / 9$ & $11 / 7$ & \\
\hline
\end{tabular}

Ficus sp. had the greatest losses in tree-fall gaps in $1^{\circ}$ cloud forest at Maquipucuna and (3) Solanum ovalifolium had the greatest losses in banana and sugarcane fields and tied for greatest losses in seeded pasture $2^{\circ}$ cloud forest at Maquipucuna. For seeds lost to seed pathogens, (1) Clusia flaviflora had the greatest losses both in closed-canopy forest and in tree-fall gaps in $1^{\circ}$ cloud forest at Guandera, (2) Cecropia sp. had the greatest losses both in closed-canopy forest and in treefall gaps in $1^{\circ}$ cloud forest at Maquipucuna and (3) Piper aduncum had the greatest losses in banana and sugarcane fields and tied for greatest losses in seeded pasture in $2^{\circ}$ cloud forest at Maquipucuna. For seeds that germinated, (1) the largest seeds of Palicourea amethystina had the greatest germination both in closed-canopy forest and in tree-fall gaps in $1^{\circ}$ cloud forest at Guandera, (2) Otoba gordoniifolia had the greatest germination both in closed-canopy forest and in tree-fall gaps in $1^{\circ}$ cloud forest at Maquipucuna and (3) Solanum ovalifolium had the greatest germination in banana fields, in sugarcane fields and in seeded pastures in $2^{\circ}$ cloud forest at Maquipucuna.

The one-way ANOVA found that forest types differed significantly $(F=7.2, P=0.01)$ for seed predation $(12.5 \%$ in $1^{\circ}$ cloud forest at Guandera, $80.5 \%$ in $1^{\circ}$ cloud forest at Maquipucuna, $64.2 \%$ in $2^{\circ}$ cloud forest at Maquipucuna) and differed significantly $(F=5.2, P=0.03)$ for seed pathogens $\left(60.1 \%\right.$ in $1^{\circ}$ cloud forest at Guandera, $7.5 \%$ in $1^{\circ}$ cloud forest at Maquipucuna, $19.2 \%$ in $2^{\circ}$ cloud forest at Maquipucuna). Within the $1^{\circ}$ forest at Guandera, ANOVA found a significant difference $(F=4.5, P=0.04)$ among tree seed species for pathogens $(61 \%$ for Solanum stenophyllum, 45\% for Palicourea amethystina, 73\% for Clusia flaviflora) and a significant difference $(F=3.3, P=0.05)$ among the tree seed species for germination $(15 \%$ for Solanum stenophyllum, 31\% for Palicourea amethystina, $13 \%$ for Clusia flaviflora). Within the $1^{\circ}$ cloud forest at Maquipucuna, ANOVA found a significant difference $(F=4.1, P=0.03)$ among tree seed species for pathogens (13\% for Cecropia sp., 7\% for Ardisia websteri, 4\% for Prestoea acuminata, 4\% for Ficus sp., 7\% for Otoba gordoniifolia) and a significant difference $(F=5.3, P=0.03)$ among the tree seed species for germination (5\% for Cecropia sp., 10\% for Ardisia websteri Pipoly, $8 \%$ for Prestoea acuminata (Willd.) H.E.Moore, 6\% for Ficus sp., 15\% for Otoba gordoniifolia). Within the $2^{\circ}$ cloud forest at Maquipucuna, ANOVA found a significant difference $(F=6.2, P=0.02)$ among tree seed species for pathogens (27\% for Cecropia monostachya C.C.Berg, 29\% for Piper aduncum, $11 \%$ for Cestrum megalophyllum Dunal, $8 \%$ for Solanum ovalifolium).

\section{Discussion}

The results obtained from both the current study and that of Myster (2015) showed large significant differences between the two cloud forests sites, which are near the two ends of the elevational ranges for Andean cloud forests (Bush et al. 2004). Pathogens were the major seed mechanism limiting forest recruitment for $1^{\circ}$ cloud forest at Guandera (Myster 1997; Myster 2003), and predation was the major seed mechanism limiting forest recruitment for both $1^{\circ}$ and $2^{\circ}$ cloud forest at Maquipucuna (see reviews in Myster 2004a; Myster 2007a). If a seed could survive both of those two filters, it had a high probability of germinating (Myster 2003; Myster and Everham, 1999). Variation in how effective

Table 3 The percentage (mean \pm standard error) of the total seeds remaining put out: in fields recovering from banana cultivation/in fields recovering from sugarcane cultivation/in fields recovering after use as seeded pasture in $2^{\circ}$ cloud forest, Maquipucuna Reserve

\begin{tabular}{lllll}
\hline Species & \% lost to predators & \% lost to pathogens & \% germinated & \% other \\
\hline Cecropia monostachya & $66 \pm 1 / 67 \pm 2 / 50 \pm 1$ & $24 \pm 2 / 25 \pm 1 / 29 \pm 3$ & $10 \pm 2 / 6 \pm 1 / 10 \pm 1$ & $0 \pm 1 / 2 \pm 1 / 11 \pm 1$ \\
Piper aduncum & $50 \pm 1 / 50 \pm 2 / 49 \pm 2$ & $30 \pm 1 / 30 \pm 1 / 29 \pm 2$ & $11 \pm 3 / 10 \pm 1 / 12 \pm 1$ & $9 \pm 1 / 10 \pm 2 / 0 \pm 1$ \\
Cestrum megalophyllum & $74 \pm 2 / 69 \pm 1 / 71 \pm 2$ & $13 \pm 1 / 11 \pm 2 / 10 \pm 1$ & $10 \pm 2 / 9 \pm 2 / 9 \pm 1$ & $3 \pm 1 / 11 \pm 3 / 9 \pm 1$ \\
Solanum ovalifolium & $77 \pm 2 / 75 \pm 1 / 71 \pm 3$ & $9 \pm 1 / 9 \pm 1 / 8 \pm 3$ & $14 \pm 1 / 14 \pm 2 / 13 \pm 1$ & $0 \pm 1 / 2 \pm 2 / 7 \pm 2$ \\
Means \% (rounded) & $67 / 65 / 60$ & $19 / 19 / 19$ & $11 / 10 / 11$ & \\
\hline
\end{tabular}


seed predation and seed pathogens (Myster 2004b), among forest types, microsites and species, determines the pattern and process of recruitment and regeneration in cloud forests. It should also be remembered that seed predators (insects, birds, mammals) differ in species preference and behavior, and also fungi (e.g. Colletotrichum sp. attacked Palicourea riparia Benth. seeds in another Neotropic Montane forest study: Myster 1997).

The level of losses for predation and pathogens in $2^{\circ}$ forest was intermediate to losses for the two $1^{\circ}$ cloud forests. This result suggests that the effects of seed predators and seed pathogens in $2^{\circ}$ cloud forest at Maquipucuna may be similar in $1^{\circ}$ cloud forest located between Guandera and Maquipucuna in elevation, and so gradients and disturbances may have comparable effects under certain circumstances (see Myster 2014a for another example where the gradient was black-water flooding and the disturbance was natural tree-fall). Thus, the proportion of seed that germinates remain largely constant as elevation increases in these cloud forests, but the major cause of seed loss shifts from being due to animal predators to being due to fungal pathogens. When the lower elevation cloud forest was converted to agriculture and then allowed to revert back to cloud forest, seeds were still lost mainly to predators but individual species loss levels corresponded with the crop that had previously been planted.

Results from previous Neotropic $1^{\circ}$ cloud forest studies conducted by several different groups have identified a number of effects relating to seed loss, i.e. (1) predators take larger seeds in preference to smaller seeds (Pringle et al. 2007); (2) $2^{\circ}$ dispersal is rare (Culot et al. 2009); (3) litter reduces seed predation (Cintra 1997), and after bat defaecation, seed were eaten at a rate of $8 \%$ per week with possible satiation (Romo et al. 2004); (4) seed predation can be reduced more by loss of soil fertility (i.e. in palm forest) than by increased flooding (i.e. in igapó forests: Myster 2014a); (5) standing water in palm forest leads to the greatest losses to pathogens, but increased flooding in igapó forests also increases loss of seeds to pathogens; and (6) seeds mainly germinate if they escape predators and pathogens (Myster and Everham 1999).

The results of the current study were also similar to those from several Neotropic $2^{\circ}$ forest studies: (1) over $75 \%$ of seeds were lost to predators in Peru old fields (Notman and Gorchov 2001); (2) more seeds were lost to predation than pathogens in Puerto Rico pasture, banana and sugarcane fields (Myster 2004a) and in their coffee fields and pastures as well $(50-75 \%$ predation, 20\%-45\% pathogens, 15\%-35\% germination: Myster 2003); (3) a reduction of seed predation from the forest into clear-cut logged areas in Peru (Notman et al. 1996); and (4) pathogens affected more seeds (16\%) than predators (9\%) in landslides at a cloud forest in Costa Rica with 69\% germination (Myster 1997). Further, for tree seedlings in the MR old fields, there was no survival in pastures, $15 \%$ survival in sugarcane fields and 25\% survival in banana fields (Myster 2007b) and the species with the smallest seeds (i.e. those of the genera Piper, Vernonia and Cecropia) survived best.

A previous study of how these same two factors (elevation vs. agriculture) affect cloud forest floristics and physical structure (Myster 2017a) found (1) Palicourea sp. was the only species found at both $1^{\circ}$ sites (Yanacocha Reserve 3400 m a.s.l, Maquipucuna Reserve $1200 \mathrm{~m}$ a.s.l), Vernonia pallens Sch.Bip., Erythrina megistophylla, Nectandra sp. and Miconia sp. were found in both $1^{\circ}$ and $2^{\circ}$ plots at Maquipucuna and Miconia sp. was the only species in common between the Maquipucuna $2^{\circ}$ plots and the $1^{\circ}$ plot at Yanacocha Reserve; (2) the mean stem size was similar between the $1^{\circ}$ Maquipucuna plots and the Yanacocha plot, but the Yanacocha plot had more total stems and more stems in each size category, which led to more basal area, above-ground biomass and canopy closure at Yanacocha compared to Maquipucuna; and (3) in the secondary plots, there were no stems larger than $29-\mathrm{cm}$ diameter at breast height (dbh) which lead to a much smaller mean stem size and lower basal area, above-ground biomass and canopy closure compared to the $1^{\circ}$ plots at both sites. For the $1^{\circ}$ cloud forest at Maquipucuna, an increase in elevation changed the species-level floristics more than conversion to, and then abandonment from, agriculture; however, a rise in elevation increased the number of stems, while agriculture reduced stem size structure (Myster 2017a).

\section{Conclusions}

The proportion of seed that germinates remains largely constant as elevation increases in these cloud forests, but the major cause of seed loss shifts from being due to predators to being due to fungal pathogens. Seeds are still lost mainly to predators when cloud forests are converted to agriculture and then allowed to revert back to cloud forest, but there are important interactions between species and past crop (here banana and sugarcane), and this type of regeneration may be faster than after tree-fall (Myster 2017a). Finally, elevation made more of a difference in recruitment and regeneration in these cloud forests than conversion to agriculture, but the key mechanism may change from predation to pathogens as elevation increases. Species differences also remain important.

\section{Acknowledgements}

I thank Jose Cando, Geovanna Coello and the staff of Guandera Biological Station for their help in executing this research. I also thank Arcenio Barras, Bernardo Castro, Jorge Reascos, Rebeca Justicia and the staff of

Maquipucuna Reserve for their help in executing this research. Finally, I thank 
D. Bonte, A. Chiarucci, M. Bull, T. Kalapos, I. Turner, V. Pillar, Y. Huang, S. Shabala, E. Bruna, C. Ballare and R. Bardgett for commenting on an earlier version of the manuscript.

\section{Funding}

Not applicable

\section{Competing interests}

The author declares that he has no competing interests.

\section{Publisher's Note}

Springer Nature remains neutral with regard to jurisdictional claims in published maps and institutional affiliations.

Received: 14 March 2017 Accepted: 22 November 2017

Published online: 05 February 2018

\section{References}

Bader, MY, Geloof, I, Rietkerk, M. (2007). High solar radiation hinders tree establishment above the alpine treeline in northern Ecuador. Plant Ecology, 191, 33-45.

Brokaw, NVL. (1982). The definition of treefall gap and its effect on measures of forest dynamics. Biotropica, 11, 158-160.

Bush, MB, Silman, MR, Urrego, DH. (2004). 48,000 years of climate and forest change in a biodiversity hot spot. Science, 303, 827-829.

Cintra, R. (1997). Leaf litter effects on seed and seedling predators of the palm Astrocaryum murumura and the legume tree Dipteryx micrantha in Amazonian forest. Journal of Tropical Ecology, 13, 709-725.

Cresswell, W, Hughes, M, Mellanby, R, Bright, S, Catry, P, Chaves, J, Freile, J, Gabela, A, Martineau, H, Macleod, R, Mcphie, F, Anderson, N, Holt, S, Barabas, S, Chapel, C, Sanchez, T. (1999). Densities and habitat preferences of Andean cloud-forest birds in pristine and degraded habitats in north-eastern Ecuador. Bird Conservation International, 9, 129-145.

Culot, L, Huynen, L, Gerard, P, Heymann, EW. (2009). Short-term post-dispersal fate of seeds defecated by two small primate species (Saguinus mystax and S. fuscicollis) in the Amazonian forest of Peru. Journal of Tropical Ecology, 25, 229-238.

Girardin, C, Malhi, Y, Aragao, L, Mamani, M, Huaraca-Huasco, W, Durand, L. (2010). Net primary productivity allocation and cycling of carbon along a tropical forest elevational transect in the Peruvian Andes. Global Change Biogeography, 16, 3176-3192.

Kappelle, M (1995). Ecology of mature and recovering Talamancan montane Quercus forests, Costa Rica. Ph.D thesis. Amsterdam: University of Amsterdam.

Myster, RW. (1997). Seed predation, disease and germination on landslides in Neotropical lower montane wet forest. Journal of Vegetation Science, 8, 55-64.

Myster, RW. (2003). Seed regeneration mechanisms over fine spatial scales on recovering coffee plantation and pasture in Puerto Rico. Plant Ecology, 166, 199-205.

Myster, RW. (2004a). Post-agricultural invasion, establishment and growth of Neotropical trees. The Botanical Review, 70, 381-402.

Myster, RW. (2004b). Regeneration filters in post-agricultural fields of Puerto Rico and Ecuador. Plant Ecology, 172, 199-209.

Myster, RW (2007a). Post-agricultural succession in the Neotropics. Berlin: SpringerVerlag.

Myster, RW. (2007b). Early successional pattern and process after sugarcane, banana and pasture cultivation in Ecuador. New Zealand Journal of Botany, $46,101-110$.

Myster, RW (2012a). Ecotones between forest and grassland. Berlin: Springer-Verlag.

Myster, R.W. (2012b) Long-term data from fields recovering after sugarcane, banana and pasture cultivation in Ecuador. Dataset Papers in Ecology 2013: Article ID 468973

Myster, RW. (2014a). Interactive effects of flooding and treefall gap formation on terra firme forest seed and seedling mechanisms and tolerances in the Amazon. Community Ecology, 15, 212-221.

Myster, R.W. (2014b) Primary vs. secondary forests in the Neotropics: two case studies after agriculture. Pp 1-42 in Forest Ecosystems: biodiversity, management and conservation. NY:Nova publishers.

Myster, RW. (2015). Seed predation, pathogens and germination in primary vs. secondary cloud forest at Maquipucuna reserve, Ecuador. Journal of Tropical Ecology, 31, 375-378.
Myster, RW. (2017a). Gradient (elevation) vs. disturbance (agriculture) effects on primary cloud forest in Ecuador: floristics and physical structure. New Zealand Journal of Forestry Science, 47, 1-7.

Myster, RW. (2017b). Does the seed rain limit recruitment, regeneration, and plant community dynamics? Ideas in Ecology and Evolution, 10, 12-16.

Myster, RW, \& Everham, EM. (1999). Germination cues across the disturbance regime in the Puerto Rican rainforest. Tropical Ecology, 40, 89-98.

Myster, RW, \& Fetcher, N. (2005). Ecotypic differentiation and plant growth in the Luquillo Mountains of Puerto Rico. Journal of Tropical Forest Science, 17, 163-169.

Myster, RW, \& Pickett, STA. (1994). A comparison of rate of succession over $18 \mathrm{yr}$ in 10 contrasting old fields. Ecology, 75, 387-392.

Myster, RW, \& Sarmiento, FO. (1998). Seed inputs to microsite patch recovery on Tropandean landslides in Ecuador. Restoration Ecology, 6, 35-43.

Nierop, K, Tonneijck, GJ, Jansen, FH, Verstraten, JM. (2007). Organic matter in volcanic ash soils under forest and paramo along an Ecuadorian altitudinal transect. Soil Science of America Journal, 71, 1119-1127.

Notman, E, \& Gorchov, DL. (2001). Variation in post-dispersal seed predation in mature Peruvian lowland tropical forests and fallow agricultural sites. Biotropica, 33, 621-636.

Notman, E, Gorchov, DL, Cornejo, F. (1996). Effect of distance, aggregation, and habitat on levels of seed predation for two mammal-dispersed Neotropical rain forest tree species. Oecologia, 106, 221-227.

Pickett, STA, \& White, PS (1985). The ecology of natural disturbance and patch dynamics. NY: Academic Press.

Pringle, EG, Alvarez-Loayzu, O, Terborgh, J. (2007). Seed characteristics and susceptibility to pathogen attack in tree seeds of the Peruvian Amazon. Plant Ecology, 193, 211-222

Rhoades, CC, \& Coleman, DC. (1999). Nitrogen mineralization and nitrification following land conversion in montane Ecuador. Soil Biology and Biochemistry, $31,1347-1354$

Rhoades, CC, Eekert, GE, Coleman, DC. (1998). Effect of pasture trees on soi nitrogen and organic matter: implications for tropical montane forest restoration. Restoration Ecology, 6, 62-270.

Romo, M, Tuomisto, H, Loiselle, BA. (2004). On the density-dependence of seed predators in Dipteryx micrantha, a bat-dispersed rain forest tree. Oecologia, $140,76-85$

Sarmiento, FO. (1997). Arrested succession in pastures hinders regeneration of Tropandean forests and shreds mountain landscapes. Environmental Conservation, 24, 14-23.

SAS (1985) User's guide: statistics, Ver. 5. SAS Institute Inc.

Whitmore, TC (1998). An introduction to tropical rain forests. Oxford: Clarendon Press. Whittaker, RH (1975). Communities and ecosystems. NY: MacMillian.

Zahawi, RA, \& Augspurger, CK. (1999). Early plant succession in abandoned pastures in Ecuador. Biotropica, 31, 123-129.

\section{Submit your manuscript to a SpringerOpen ${ }^{\circ}$ journal and benefit from:}

- Convenient online submission

- Rigorous peer review

- Open access: articles freely available online

- High visibility within the field

- Retaining the copyright to your article

Submit your next manuscript at $>$ springeropen.com 